\title{
AN APPEAL FOR HELP
}

A. M. PROVICK, Hazelcliffe, Sask.

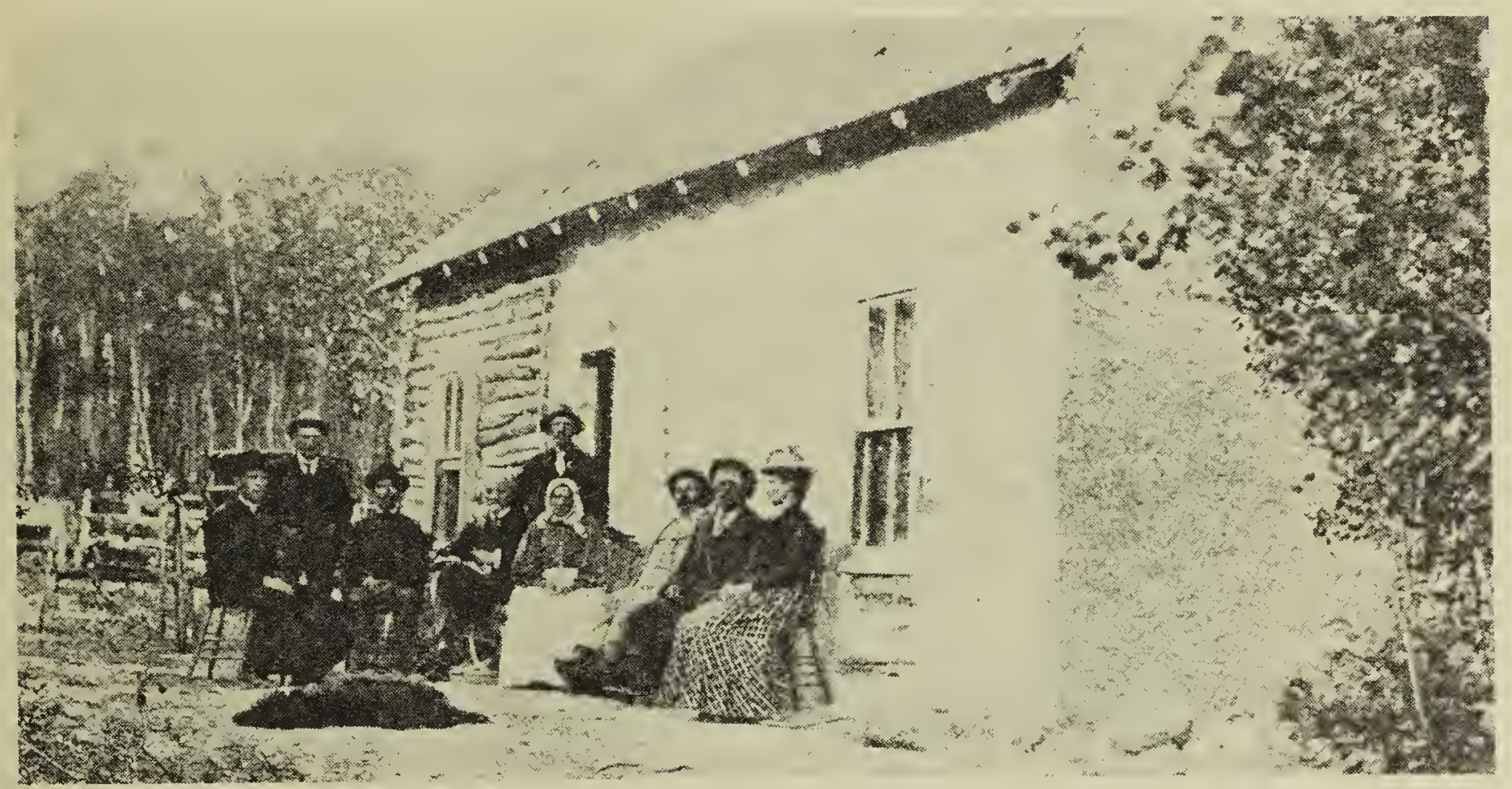

Site of Kaposuar Post Office. Stephen Barath, P.M.

Since my letter re post office sites appeared in the last issue of The Blue Jay, I have received some encouragement, favourable comment, and offers of assistance, in a project which I have revealed to a number of interested people. It is briefly this: to form a booklet or scrapbook containing all the information about any particular post office in the N.W.T., Sask., and Assiniboia, opened up to 1906. What could be included would be: (1) Photograph of each post office, (2) Location, (3) First postmaster and a bit about him (or her), (4) Something about the mail contracts and carriers, if possible. This is often most interesting.

The dates of opening are not too important as I can get this from philatelic publications or from Ottawa whenever they are inclined to be co-operative.

Time is running out-very few original farm homes or village post offices still remain. Many of them are lying in old photograph albums, etc. There is no time like right now to preserve what is left, and I am willing to collect this from interested readers and try to organize the material into something which I hope will be of permanent interest. I hope that in time the booklet or whatever form it takes will be circulated amongst interested contributors. So won't you drop me a line right away so we can start the ball rolling?

\section{ALSO INTERESTED}

I, too, am interested in the postal history of Saskatchewan. We have in our vicinity a little post office called Cramerburg, that has been there since early days and is still going strong. Near this post office, to remind us that time is not standing still, is a deep ditch being put in by the P.F.R.A., to drain a large area of land which is under water during wet years.-Isabelle Powell, Swift Current.

\section{MASS MIGRATION OF JUNCOS}

J. TURNQUIST, Wallwort, Sask.

According to my bird records it was on the 25th of April, 1947, when my late friend, J. D. Ritchie and I sat by my window and watched a flock of Slate-coloured Juncos go by on their way north. We estimated that there were at least five thousand of them. Some were walking, some hopping, others flying, but all were feeding on seeds that I had put out. We noticed a few Redpolls among them. After this group had passed I saw no more of them that spring. It would appear that they all went on one mass migration wave. It was a grand sight. 